\title{
Probiotics prevent growth deficit of colon wall strata of malnourished rats post-lactation
}

\author{
DIRLENE P. LIMA ${ }^{1}$, JORGE F. DE AZEVEDO ${ }^{2}$, CATCHIA HERMES-ULIANA ${ }^{3}$, GILBERTO ALVES ${ }^{4}$, \\ DÉBORA M.G. SANT'ANA ${ }^{5}$ and EDUARDO J.A. ARAÚJO ${ }^{6}$ \\ ${ }^{1}$ Programa em Ciência Animal, Universidade Paranaense (UNIPAR), 87502-210 Umuarama, PR, Brasil \\ ${ }^{2}$ Departamento de Ciências Biológicas, Faculdades Associadas de Ariquemes (FAAR), 78932-000 Ariquemes, RN, Brasil \\ ${ }^{3}$ Programa de Ciências Farmacêuticas, Universidade Estadual de Maringá (UEM), 87020-900 Maringá, PR, Brasil \\ ${ }^{4}$ Departamento de Nutrição, Universidade Paranaense (UNIPAR), 87502-210 Umuarama, PR, Brasil \\ ${ }^{5}$ Departamento de Ciências Morfológicas, Universidade Estadual de Maringá (UEM), 87020-900 Maringá, PR, Brasil \\ ${ }^{6}$ Departamento de Histologia, Universidade Estadual de Londrina (UEL), 86051-980 Londrina, PR, Brasil \\ Manuscript received on August 9, 2010. accepted for publication on January 1, 2011
}

\begin{abstract}
The objective of this study was to analyze morphometrically the colon wall strata of malnourished rats supplemented with probiotics. Sixteen recently weaned Wistar rats (Rattus norvegicus) were distributed into four groups: animals that received commercial chow $(\mathrm{G} 1, \mathrm{n}=4)$; animals that received the same feed as $\mathrm{G} 1$ and were supplemented with probiotics $(\mathrm{G} 2, \mathrm{n}=4)$; animals that received chow with $4 \%$ of proteins $(\mathrm{G} 3$, $\mathrm{n}=4)$; animals that received the same feed as $\mathrm{G} 3$ and were supplemented with probiotics $(\mathrm{G} 4, \mathrm{n}=4)$. After 12 weeks, the proximal colon was collected and submitted to histological processing. Three- $\mu \mathrm{m}$ cuts were stained with H.E., Periodic Acid Schifff (P.A.S.) + diasthasis solution and Alcian Blue (A.B.) pH 2.5 and pH 1.0. The morphometric analysis of the intestinal wall showed that the supplementation with ABT-4 probiotic culture prevents the growth deficit of colon wall strata that normally occurs in malnourished rats right after lactation. Besides, no alteration was observed in the proportion of the number of globet cells in relation to the number of enterocytes in malnourished rats, regardless of the supplementation with probiotics.
\end{abstract}

Key words: histology, large intestine, malnourishment, morphometry, probiotics.

\section{INTRODUCTION}

The digestive tube is a kinetic micro ecosystem that shelters a complex dynamic microorganism population that contributes to the regular performance of the intestine physiology (Andoh and Fujiyama 2006). The probiotic microrganisms are within this group (Alander 1999, Bielecka et al. 2002, Capriles et al. 2005).

Correspondence to: Eduardo José de Almeida Araújo E-mail:ejaaraujo@gmail.com
Probiotics are defined as live microbial supplements that, in appropriate amounts, affect their receptor beneficially through the improvement of the intestinal microbial balance and benefits to health (Food and Agriculture Organization of United Nations, World Health Organization 2001).

The highest metabolic activity and concentration of these microorganisms are found in the large intestine, reaching 1011 to 1012 UFC/g (Bedani and Rossi 2008). This predominant colonization 
of probiotics in segments of the large intestine can be explained by the favorable conditions to the bacterial proliferation, as well as by the slow peristaltism and nutritional supply (Bielecka et al. 2002, Brady et al. 2000).

Several studies have demonstrated that probiotics estimulate cell proliferation of the immune system associated to the intestinal mucosa (Erickson and Hubbard 2000, Cano and Perdigón 2003, Villena et al. 2006, De Souza et al. 2007, Dewan et al. 2007, Kaburagi et al. 2007, Pitsouni et al. 2009), which may contribute to the control of infections, as well as to their prevention in the case of diseases derived from nutritional deficiency. On the other hand, there are few studies that evaluated the action of probiotics on the intestinal morphology of malnourished animals, and were mostly restricted only to the study of the mucosa (Allori et al. 2000, Cano et al. 2002, Dock et al. 2004a, b, Dock-Nascimento et al. 2007). A single study examined the different strata of the intestinal wall by examining only the small intestine (J.F. de Azevedo et al., unpublished data). Considering which was presented above, this study aimed to analyze morphometrically the colon wall strata of malnourished rats supplemented with probiotics.

\section{MATERIALS AND METHODS}

This study was previously approved by the Committee of Ethics in Research Involving Animal Experimentation of UNIPAR (registration $\mathrm{n}^{\circ}$. 11732), that follow the regulations of the Brazilian Comission of Animal Experimentation (COBEA).

\section{EXPERIMENTAL OUTLINE}

Sixteen recently weaned (21 days) $42.9 \pm 1.8 \mathrm{~g}$ male Wistar rats (Rattus norvegicus) that were kept in individual cages in a room under controlled temperature $\left( \pm 25^{\circ} \mathrm{C}\right)$ and dark/bright cycle (every 12 hours). During the whole experiment, the rats had water and feed ad libitum.
The animals were randomly separated into four groups: G1 - animals that received the commercial chow for rodents NUVILAB ${ }^{\odot}(n=4) ; G 2$ - animals that received the same feed as G1 and that were supplemented with fermented lacteous drink containing probiotics, through gavage performed five times a week $(n=4)$; $G 3$ - animals that received modified chow so that the protein content was reduced to $4 \%$, following the protocol proposed by Araújo et al. (2005) ( $\mathrm{n}=4)$; G4 animals that received the same feed as G3 and that were supplemented as described before $(n=4)$. G1 and G3 animals went through he same gavage stress, but they received only $10 \%$ skimmed powder milk (Molico, Nestlé ${ }^{\odot}$ ) in a volume of $1 \%$ of the average group body weight.

\section{STARTER CULTURE}

A commercial culture to produce yogurt was added by probiotics (ABT4 - Chr Hansen, Denmark) consisting of the following microorganisms: Lactobacillus delbrueckii ssp. bulgaricus; Streptococcus salivarius ssp. thermophilus; Bifidumbacterium bifidus and Lactobacillus acidhophillus. The culturewas replicated in skimmed powered milk (Molico, Nestlé ${ }^{\odot}$ ) at $10 \%$ of total solids and sterilized in autoclave at $127^{\circ} \mathrm{C}$ for $15 \mathrm{~min}$, and then it was incubated at $42^{\circ} \mathrm{C}$ for $48 \mathrm{~h}$, and the final counting was done in MRS Revitec ${ }^{\mathbb{C}}$ (Mann,Rugosa,Shaper) mean of $1010 \mathrm{UFC} / \mathrm{mL}$. Dairy drink containing probiotic culture was done considering $1 \%$ of the average group weight.

\section{EUTHANASIA AND COLLECTION OF THE COLON}

After 12 weeks, the rats of each group fasted for 12 hours and were weighed and anesthetized with the following protocol (Pachaly et al. 2003): Acepran $(1.26 \mathrm{~mL} / \mathrm{Kg})+$ Ketamine-10\% $(1.26 \mathrm{~mL} / \mathrm{Kg})+$ Xylazine-2\% (0.42 mL/Kg) and Atropine-1\% (0.22 $\mathrm{mL} / \mathrm{Kg}$ ), injected via intramuscular. Laparotomy 
was done to remove the proximal colon of each animal, measuring its respective length and width with the help of a millimeter ruler.

MORPHOMETRIC ANALYSIS OF THE INTESTINAL WALL

A three-centimeter ring of the proximal part of each collected colon was fixed in Bouin solution for 2 hours, dehydrated in an ascending series of ethylic alcohol, diaphanized in xylol and included in paraffin to obtain 3- $\mu \mathrm{m}$ transversal cuts that were stained with Hematoxylin and Eosin (H.E.); Periodic Acid Shiff (P.A.S.) + diasthasis solution - to detect neutral mucins and labile sialomucins; Alcian-Blue (A.B.) pH 2.5 - to detect sialomucins and sulfomucins; and Alcian-Blue (A.B.) $\mathrm{pH} 1.0$ - to detect sulfomucins, following the protocol described by Myers et al. (2008). For techniques to detect glycoconjugates (P.A.S. and A.B.), countercoloration with hematoxylin was performed.

The morphometric analysis of the intestinal wall was done from the images of the stained cuts with H.E., captured by a digital camera (Moticam $^{(}$ 2000, 2.0 Megapixel) mounted on a trinocular light microscope $\left(\right.$ MOTIC ${ }^{\odot}$ B5). The captured images with the help of a 10x lens were used to measure the total thickness of the wall and the mucosa; and the 40x lens was used to measure the height of enterocytes (from basal membrane to striated border), depth of crypts, thickness of the submucosa and thickness of the external muscle. Eighty measurements were made in semi-serial cuts, uniformly distributed along the intestinal circumference of each structure of each animal, totaling 320 measures per group.

\section{QUANTITATIVE ANALYSIS}

For each 2,000 consecutive enteorocytes, the proportion of globet cells was calculated. For that, from each intestinal segment collected from each animal, 16 images of cuts, which were stained using each histochemical technique realized in this study, were used for the described system with a 40x lens. Therefore, for each collected intestinal segment, a total of 192 images of the mucosa stained with P.A.S. + diasthasis solution, A.B. pH 2.5 and A.B. pH 1.0.

\section{STATISTICAL ANALYSIS}

The collected numerical data were submitted to D'Agostino-Pearson or Shapiro Test to verify the type of distribution. The data with normal distribution are presented as mean \pm standard deviation. In this case, to compare the groups, independent-samples-Student's t Test was used. The data with free distribution are presented as median (percentile 25; percentile 75). Thus, the comparison among other groups was made by the Mann-Whitney Test. The compared groups were: G1 x G2, G1 x G3, G1 x G4, G2 x G4 and G3 x G4. In all statistical tests, the values of $p$ were smaller than 0.05 was considered significant.

\section{RESULTS AND DISCUSSION}

In this study, a proteic malnourishment induction protocol, which had already proved to be efficient in rats (Araújo et al. 2005), was used. The results about the food intake, body weight, naso-anal length and analyses of blood parameters had already been published previously (D.P. de Lima et al., unpublished data) and demonstrated that the animals that had received modified feed really became malnourished. However, it is important to emphasize that this investigation intended to evaluate whether or not malnourished rats, when supplemented with probiotics, exhibit different effects from the already known ones, regarding the repercussions of protein malnourishment in the colon morphology. 
TABLE I

Mean \pm standard deviation of the length, width and area of the colon of rats submitted to protein malnourishment and supplemented with probiotics.

\begin{tabular}{ccccc}
\hline Measurements & G1 & G2 & G3 & G4 \\
\hline Length $(\mathrm{cm})$ & $7.13 \pm 0.95$ & $8.75 \pm 1.04$ & $6.63 \pm 0.75$ & $5.88 \pm 0.85$ \\
Width $(\mathrm{cm})$ & $1.10 \pm 0.29$ & $8.75 \pm 1.04$ & $6.63 \pm 0.75$ & $1.48 \pm 0.73$ \\
Area $\left(\mathrm{cm}^{2}\right)$ & $8.04 \pm 3.30$ & $7.28 \pm 4.60$ & $8.63 \pm 3.09$ & $9.11 \pm 8.90$ \\
\hline
\end{tabular}

G1: commercial chow for rodents; G2: commercial chow + supplementation with probiotics; G3: chow with $4 \%$ proteins; G4: chow with $4 \%$ proteins + supplementation with probiotics. Comparison of values among different groups (G1 x G2, G1 x G3, G1 x G4, G2 x G4 and G3 x G4) was made using independentsamples-Student's t Test, considering $\alpha=0.05$. There was no significant difference among the groups.

Therefore, it was observed that the collected colons did not have their dimensions (length, width and area) altered by the malnourishment nor the probiotic supplementation (Table I), differently from what was observed in a parallel study on the jenunun of these animals, which had a smaller area in animals from G3 when compared to the ones from G1 ( J.F. de Azevedo et al., unpublished data). Then, it is worth emphasizing that the literature shows that the protein malnourishment generally causes atrophy of the small intestine organs (Firmansyah et al. 1989, Meilus et al. 1998, Torrejais et al. 1995, Natali et al. 2000, 2005, Brandão et al. 2003) however, the same does not always occur in the large intestine (Schoffen et al. 2005, Hermes et al. 2008). This can be explained as a consequence to the cell turnover that is normally higher in the small intestine, since there is the presence of numerous villis to increase the contact surface between the mucosa and the intestinal lumen content, and hipoproteic diets can not offer the needed amount of aminoacids to support this phenomenon.

Although the colon dimensions have not been altered, the thickness of the wall strata was evaluated in order to notice possible microscopic alterations (Table II), mainly the ones already known as effects of protein malnourishment. Therefore, it was verified that the mucosa thickness presented gain deficit in protein malnourished animals (G3) when compared to eutrophic ones (G1) that were not supplemented with probiotics $(p<0.05)$. On the other hand, the supplementation with probiotics (G4) provided a protective effect to the mucosa; this damage is generally observed in protein malnourishment (Viteri and Schneider 1974, Rodrigues et al. 1985, Torrejais et al. 1995, Natali et al. 2000, Schoffen et al. 2005, De Azevedo et al. 2007, Hermes et al. 2008). It is important to point out that the eutrophic animals were also supplemented with probiotics (G2) and presented thicknening of the mucosa when compared to G1, corroborating the studies that describe the proliferative effect induced by these microorganisms (Dock et al. 2004a, AguilarNascimento et al. 2006, Dock-Nascimento et al. 2007, $\mathrm{Ng}$ et al. 2009). In a parallel study of the jejunum of the same animals, it was observed that an equivalent result to these parameters (J.F. de Azevedo et al., unpublished data).

Probiotics are able to stimulate the immunological system (Erickson and Hubbard 2000, Cano and Perdigón 2003, Copolla and Gil Turnes 2004, Villena et al. 2006, De Souza et al. 2007, Dewan et al. 2007, Kaburagi et al. 2007, Pitsouni et al. 2009) it is suggested that the deficit prevention in the tissue formation of the mucosa due to malnourishment be balanced because of the proliferation of conjunctive tissue cells (the lamina propria), which explains the results observed in animals of G4. Besides, the height 
TABLE II

Median and percentiles 25 and 75 of height of enterocytes, thickness of mucosa, depths of crypts, thickness of submucosa and external muscle, and total thickness of colon wall of malnourished rats submitted to protein malnourishment and supplemented with probiotics.

\begin{tabular}{ccccc}
\hline Parameters $(\boldsymbol{\mu m})$ & G1 & G2 & G3 & G4 \\
\hline Height of & 25.94 & 26.98 & 24.93 & 24.10 \\
Enterocytes & $(23.43 ; 28.81)^{\mathrm{a}}$ & $(24.65 ; 30.15)^{\mathrm{b}}$ & $(22.19 ; 27.22)^{\mathrm{bc}}$ & $(22.05 ; 26.43)^{\mathrm{d}}$ \\
Mucosa & 232.84 & 250.18 & 190.64 & 236.28 \\
& $(201.86 ; 266.66)^{\mathrm{a}}$ & $(196.69 ; 275.13)^{\mathrm{ab}}$ & $(148.07 ; 230.66)^{\mathrm{c}}$ & $(194.28 ; 264.24)^{\mathrm{da}}$ \\
Depth of Crypts & 159.96 & 161.69 & 150.87 & 163.85 \\
& $(145.83 ; 198.02)^{\mathrm{a}}$ & $(127.60 ; 182.20)^{\mathrm{bc}}$ & $(131.78 ; 173.83)^{\mathrm{b}}$ & $(141.78 ; 191.12)^{\mathrm{c}}$ \\
Submucosa & 29.07 & 30.27 & 27.33 & 22.81 \\
& $(23.46 ; 39.53)^{\mathrm{a}}$ & $(24.55 ; 38.02)^{\mathrm{ab}}$ & $(23.31 ; 32.50)^{\mathrm{bc}}$ & $(20.82 ; 27.29)^{\mathrm{d}}$ \\
External Muscle & 247.02 & 241.88 & 222.66 & 244.42 \\
& $(209.67 ; 268.07)^{\mathrm{ac}}$ & $(200.82 ; 259.13)^{\mathrm{ab}}$ & $(191.76 ; 241.98)^{\mathrm{b}}$ & $(214.46 ; 296.85)^{\mathrm{c}}$ \\
Total Thickness of & 914.21 & 991.24 & 851.67 & 915.77 \\
Colon Wall & $(856.17 ; 1039.29)^{\mathrm{a}}$ & $(844.32 ; 1095.15)^{\mathrm{a}}$ & $(797.74 ; 915.68)^{\mathrm{b}}$ & $(835.40 ; 1049.03)^{\mathrm{a}}$ \\
\hline
\end{tabular}

G1: commercial chow for rodents; G2: commercial chow + supplementation with probiotics; G3: chow with 4\% proteins; G4: chow with $4 \%$ proteins + supplementation with probiotics. Medians followed by different letters on the same line are significantly different. Comparison of values among different groups (G1 x G2, G1 x G3, G1 x G4, G2 x G4 and G3 x G4) was made using Mann-Whitney Test, considering $\alpha=0.05$.

of enterocytes must be considered as the depths of the intestinal crypts reduced in animals of G3 when compared to the ones of $\mathrm{G} 1(\mathrm{p}<0.05)$ and that these alterations can be avoided in animals supplemented with probiotics $(\mathrm{G} 4)(\mathrm{p}<0.05)$. Considering these parameters, the supplementation with probiotics carried out in eutrophic animals presented effects that question their possible beneficial action since the colon enterocytes of these animals (G2) were higher and their crypts were deeper $(p<0.05)$. Higher enterocytes increase the trajectory of molecules that diffuse the intestinal lumen towards the lamina propria, probably interfering in the absorption rate. The increase of crypt depth indicates a higher cell proliferation that can be the result of the need to renew those that form the intestinal epithelium, a factor alluded to the aggression to this tissue (Elia and Souza 2001).

It is worth remembering that protein malnourishment may cause a smaller cadherin expression in enterocytes (Dalçik et al. 2003) and that this phenomenon can compromise the intestinal barrier since they are important molecules to cell adhesion. On the other hand, studies have shown that probiotics are able to increase the efficiency of the intestinal barrier (Menningen and Bruewer 2009), which is very adequate in malnourishment situations.

Regarding the submucosa, it was observed that malnourished animals presented a gain deficit of $21.5 \%$ in relation to eutrophic ones, and that the supplementation with probiotics descreased the loss in $\sim 72 \%(\mathrm{p}<0.05)$. As this stratum consists of a dense conjunctive tissue, it is suggested that malnourishment can cause a synthesis reduction of extracellular matrix proteins as well as increase the degradation of this tissue component in order to make endogenous aminoacids available as a compensation mechanism, similarly to the descriptions made for the dermis of malnourished individuals (Waterlow 1996). The results of this study indicate that the supplementation with 
probiotics reduces this phenomenon; however, the involved mechanisms still unknown. In a parallel study on the jejunum of these animals, no alteration of this stratum was observed (J.F. de Azevedo et al., unpublished data), indicating that rats tend to preserve the submucosa in the small intestine when compared to the large intestine. Unfortunately the morphometric studies of the intestinal wall generally do not evaluate the submucosa, not allowing the comparison of results from this study to the ones in the literature.

Similarly to what happens to the mucosa, cases of protein malnourishment usually cause reduction of the external muscle thickness, corroborating the results of this study. This atrophy is also explained by the increase of autolysis in order to make endogenous aminoacids available to tissues that have a smaller regeneration capability or that have indispensable functions to the survival of the organism (Deo 1969). On the other hand, malnourished rats supplemented with probiotics did not show this deficit $(\mathrm{p}<0.05)$, which suggests that the number and the diameter of the cell that form this stratum were not altered by the lack of protein in the diet, ratifying the beneficial effect of the intake of these microorganisms. Similar results were observed in the jejunum of these animals from this study (J.F. de Azevedo et al., unpublished data) however, in this case, the possible protective effect of probiotics lessened the deleterious effect of malnourishement. A possible explanation for these findings is that probiotics are present in higher amounts in the large intestine (Brady et al. 2000, Bielecka et al. 2002, Bedani and Rossi 2008), when compared to the segments of the small intestine, which somehow may favor the colon to maintain its tissue structure. Differently from recently weaned rats used in this study, malnourished adult rats did not present the same alterations in the thickness of the external muscle (Hermes et al. 2008) when the same protocol was used, corroborating that the results of studies involving experimental nutrition depend on the age of the utilized animals.
As a consequence of the thickness reduction of all colon wall strata, it was observed that in malnourished animals (G3), the total thickness of the wall has a growth deficit of $\sim 7 \%$, but remained unaltered in malnourished rats supplemented with probiotics, even considering the discrete reduction of the submucosa that occurred in this animals $(p<0.05)$. In reality, the supplementation with probiotics was efficient to prevent damages that generally occur in the mucosa and external muscle of malnourished rats. These findings ratify the beneficial effect of the intake of these microorganisms, including in cases when the amount of proteins present in the provided diet does not meet the demand of the involved organism. Possibly, the increase of the intestinal barrier efficiency (Menningen and Bruewer 2009) and the stimulation of the immunological system (Erickson and Hubbard 2000, Cano and Perdigón 2003, Copolla and Turnes 2004, Villena et al. 2006, De Souza et al. 2007, Dewan et al. 2007, Kaburagi et al. 2007, Pitsouni et al. 2009) promoted by the action of probiotics must have collaborated to a higher absorption of available aminoacids in the hypoproteic feed. Studies on this hypothesis can corroborate future investigations that aim to optimize the access to functional foods or supplements containing probiotics in cases of malnourishment in humans. Further investigation is necessary to evaluate the thickness preservation of the intestinal strata qualitatively as well as to analyze the enteric nervous system as it represents the main nervous control of the intestinal functions (Furness 2006).

Regarding the number of globet cells in relation to the number of enterocytes, it was observed that the malnourishment as well as the intake of probiotics did not infer in this relation (Table III), regardless of the mucin types (neutral or acid), that were also observed in the jejunum of the same animals (J.F. de Azevedo et al., unpublished data). It is important to note again that the age of the animals can also be a variable that is involved in these results. In a study done with adult malnourished rats using the same 
TABLE III

Mean \pm standard deviation of the proportion of globet cells/enterocytes in the colonic mucosa of rats submitted to protein malnourishment and supplemented with probiotics.

\begin{tabular}{ccccc}
\hline Technique & G1 & G2 & G3 & G4 \\
\hline $\begin{array}{c}\text { P.A.S. }+ \\
\text { diasthasis } \\
\text { solution }\end{array}$ & $0.39 \pm 0.04$ & $0.42 \pm 0.04$ & $0.37 \pm 0.04$ & $0.33 \pm 0.07$ \\
$\begin{array}{c}\text { A.B. pH2.5 } \\
\text { A.B. pH1.0 }\end{array}$ & $0.38 \pm 0.07$ & $0.37 \pm 0.08$ & $0.38 \pm 0.08$ & $0.33 \pm 0.05$ \\
\hline
\end{tabular}

G1: commercial chow for rodents; G2: commercial chow + supplementation with probiotics; G3: chow with $4 \%$ proteins; G4: chow with $4 \%$ proteins + supplementation with probiotics; P.A.S.: Periodic Acid Schiff; A.B.: Alcian blue, Comparison of values among different groups (G1 x G2, G1 x G3, G1 x G4, G2 x G4 and G3 x G4) was made using independent-samples-Student's t Test, considering $\alpha=0.05$. There was no significant difference among the groups.

protocol, it was observed that the number of globet cells that produce neutral mucins, sialomucins and sulfomucins was reduced (Hermes et al. 2008). It is necessary to be careful when comparing these results since the utilized methodology by the authors of the mentioned investigation is different from the one used in this study as they evaluated the number of globet cells in a $0.2 \mathrm{~mm}^{2}$ area of the colon mucosa. On the other hand, rats that received an aproteic diet presented reduction of the number of globet cells (Dock-Nascimento et al. 2007). In the latter study, the authors also observed that the supplementation with probiotics $\left(10^{6} \mathrm{UFC} / \mathrm{mL}\right.$ of Strepctococcus thermophilus and Lactobacillus helveticus) collaborates to the restauration of the cell number. There are no other studies in literature that assessed the population of globet cells in malnourished rats supplemented with probiotics.

It is concluded that the supplementation with ABT-4 probiotics for 12 weeks prevents the growth deficit of the colon wall strata that generally occurs in malnourished rats right after lactation. Besides, in this study, there was no alteration in the proportion of the number of globet cells in relation to the number of enterocytes in malnourished rats, regardless the supplementation with probiotics.

\section{ACKNOWLEDGMENTS}

The authors thank Universidade Paranaense (UNIPAR) for the financial support.

\section{RESUMO}

Objetivou-se analisar morfometricamente os estratos da parede do cólon de ratos desnutridos e suplementados com probióticos. Utilizaram-se 16 ratos (Rattus norvegicus) Wistar, recém-desmamados, distribuídos em quatro grupos: animais que receberam a ração comercial $(\mathrm{G} 1, \mathrm{n}=4)$; animais que receberam a mesma ração do grupo G1 e que foram suplementados com probióticos $(\mathrm{G} 2, \mathrm{n}=4)$; animais que receberam uma ração com $4 \%$ de proteínas $(\mathrm{G} 3, \mathrm{n}=4)$; animais que receberam a mesma ração do grupo $\mathrm{G} 3$ e que foram suplementados com probióticos $(\mathrm{G} 4, \mathrm{n}=4)$. Após 12 semanas, o cólon foi coletado e submetido a rotina de processamento histológico. Cortes de $3 \mu \mathrm{m}$ foram corados com H.E., Periodic Acid Schifff (P.A.S.) + solução de diástase e Alcian Blue (A.B.) pH 2,5 e pH 1,0. A análise morfométrica da parede intestinal revelou que a suplementação com a cultura probiótica ABT-4 previne o déficit de crescimento dos estratos da parede do cólon que normalmente ocorre em ratos desnutridos proteicamente pós-lactação. Além disso, 
não se observou alteração na proporção do número de células caliciformes em relação ao número de enterócitos nos ratos desnutridos, independentemente da suplementação com probióticos.

Palavras-chave: histologia, intestino grosso, desnutrição, morfometria, probióticos.

\section{REFERENCES}

Aguilar-NASCIMENTO JE, PADRo S, ZAFFANi G, SALOMÃo AB, NeVES JS, DOCK-NASCIMENTO DB, MELlo PRB AND OKAY TS. 2006. Perioperative administration of probiotics: effects on immune response, anastomic resistance and colonic mucosal trophism. Acta Cir Bras 21: 80-83.

ALANDER M. 1999. The effect of probiotic strains on the microbiota of the simulator of the human intestinal microbial ecosystem. Int J Food Microbiol 46: 71-79.

Allori C, Aguero G, De Ruiz-Holgado AP, NAder OM AND PERDigón G. 2000. Gut mucosa morphology and microflora changes in malnourished mice after renutrition with Milk and administration of Lactobacillus casei. J Food Prot 63: 83-90.

ANDOH A AND FUJIYAMA F. 2006. Therapeutic approaches targeting intestinal microflora in inflammatory bowel disease. World J Gastroentero 12: 4452-4460.

ARAúJo EJA, SANT'ANA DMG, MOLINARI SL AND MIRANDA NETO MH. 2005. Biometric and food consumption parameters of rats subjected to hypoproteic and hipercaloric diet. Arq Cienc Vet Zool Unipar 8: 131-138.

BEDANI R AND Rossi EA. 2008. Microbiota intestinal e probióticos: implicações sobre o câncer de cólon. J Port Gastroenterol 15: 19-28.

BieleckA M, BiedRZyCKA E AND MaJKOWSKA A. 2002. Selection of probiotics and prebiotics for synbiotics and confirmation of their in vivo effectiveness. Food Res Int 35: $125-131$.

BRADY LJ, GALLAHER DD AND BUSTA FF. 2000. The role of probiotic cultures in the prevention of colon cancer. $\mathrm{J}$ Nutr 25: 410-414.

Brandẽo MCS, De Angelis RC, De Souza RR, Froes LB AND LIBERTI EA. 2003. Effects of pre and postnatal protein energy deprivation on the myenteric plexus of the small intestine: a morphometric study in weanling rats. Nutr Res 75: 7-15.

Cano PG, Agoero G and Perdigón G. 2002. Adjuvant effects of Lactobacillus casei added to a renutrition diet in a malnourished mouse model. Biocell 26: 35-48.

CANO PG AND PERDIGÓN G. 2003. Probiotics induce resistance to enteropathogens in a re-nourished mouse model. $\mathrm{J}$ Dairy Res 70: 433-440.

Capriles VD, Silva KE And Fisberg M. 2005. Prebióticos, Probióticos e Simbióticos: nova tendência no mercado de alimentos funcionais. Nutr Bras 6: 27-333.

Coppola MM and TuRnes CG. 2004. Probióticos e Resposta Imune. Cienc Rural 4: 21-35.
DALÇIK C, FILIZ S, FILIZ TM AND DALÇIK H. 2003. Immunohistochemical analysis of neural cell adhesion molecule (N-CAM) and pan-cadherin in the small intestine of intrauterine growth-retarded newborn rats caused by maternal protein malnutrition. Acta Histochem 2: 183-190.

De Azevedo JF, Hermes C, MANZANo MA, AraúJo EJA AND SANT'ANA DMG. 2007. Análise morfométrica da parede intestinal do íleo de ratos submetidos à intensa carência de proteínas. Arq Cienc Vet Zool Unipar 10: 85-89.

DE SouzA MM, Aguilar-Nascimento JE AND DockNASCIMENTO DB. 2007. Effects of budesonide and probiotics enemas on the systemic inflammatory response of rats with experimental colitis. Acta Cir Bras 22: 40-45.

DEO MG. 1969. Biology of protein-calorie malnutrition. Rev Nutr Diet 32: 49-95.

DeWAN P, Kaur I, ChatTopadhya D, FARIDI MMA AND AgARWAL KN. 2007. A pilot study on the effects of curd (dahi) and leaf protein concentrate in children with protein energy malnutrition (PEM). Indian J Med Res 126: 199-203.

Dock DB, Aguilar-Nascimento JE AND LATORRACA MQ. 2004 b. Probiotes enhance the recovery of gut atrophy in experimental malnutrition. Biocell 28: 143-150.

DOCK DB, LATORRACA MQ, AGUILAR-NASCIMENTO JE AND GOMES-DA-SILVA MHG. 2004a. Probiotics enhance recovery from malnutrition and lessen colonic mucosal atrophy after short-term fasting in rats. Nutr 20: 473-476.

DocK-NASCIMENTO DB, KelLY J AND AGUIAR-NASCIMENTO JE. 2007. Rapid restoration of colonic goblet cells induced by a hydrolyzed diet containing probiotics in experimental malnutrition. Acta Cir Bras 22: 72-76.

ELIA SCC AND SOUZA HSP. 2001. Imunologia da mucosa intestinal: da bancada ao leito. Editora Atheneu, Rio de Janeiro, p. 1-147.

ERICKSON KL AND HUBBARD NE. 2000. Probiotic immunomodulation in health and disease. J Nutr 130: 403-409.

FAO/WHO - Food and Agriculture Organization of the United Nations / World Health Organization. 2001. Evaluation of health and nutritional properties of probiotics in food including powder milk with live lactic acid bacteria. Córdoba, p. 1-34. Disponível em: <ftp://ftp.fao.org/es/esn/ food/probioreport_en.pdf>. Acesso em: 20 fev. 2009.

Firmansyah A, Suwandito L, Penn D and Lebenthal E. 1989. Biochemical and morphological changes in the digestive tract of rats after prenatal and postnatal malnutrition. Am J Clin Nutr 50: 261-268.

FURNESS JB. 2006. The enteric nervous system. Malden: Blackwell Publishing 1: 1-28.

Hermes C, Almeida EC, Souza EA, Araújo EJA AND SANT'ANA DMG. 2008. Efeitos da desnutrição protéica severa sobre aspectos morfológicos e quantitativos dos neurônios mientéricos do cólon ascendente de ratos. Arq Cienc Vet Zool Unipar 11: 13-16.

Kaburagi T, Yamano T, FukUshima Y, Yoshino H, Mito N AND SATO K. 2007. Effect of Lactobacillus johnsonii La1 on immune function and serum albumin in aged and malnourished aged mice. Nutr 23: 342-350. 
Meilus M, Natali MRM And MiRAnda Neto MH. 1998. Study of the myenteric plexus of the ileum of rats subjected to proteic undernutrition. Rev Chil Anat 16: 9-14.

MENNINGEN R AND BRUEWER M. 2009. Effect of probiotics on intestinal barrier function. Ann NY Acad Sci 1165:183-189.

Myers RB, Fredenburgh JL AND GRIZZLE WE. 2008. Carbohydrates. In: BANCROFT JD AND GAMBLE M (Eds), Theory and practice of histological techniques, Philadelphia: Churchill Livingstone Elsevier, Philadelphia, USA, p. 161-186.

NATALI MRM, MiRANDA NETO MH AND ORSI AM. 2000. Effect of hypoproteic diet supply on adult Wistar on adult rats (Rattus Norvegicus). Acta Sci 22: 567-571.

NATALI MRM, MOLINARI SL, VALENTINI LC AND MiRANDA NeTO MH. 2005. Morphoquantitative evaluation of the duodenal myenteric neuronal population in rats fed with hypoproteic ration. Biocell 29: 39-46.

NG SC, HART AL, KAMm MA, StagG AJ AND KNIGHT SC. 2009. Mechanisms of action of probiotics: recent advances. Inflamm Bowel Dis 15: 300-310.

PaChaly JR, SANT'ANA DMG, ARAúJo EJA, CifFoni EMG AND ACCO A. 2003. Anestesia of Wistar rats (Rattus norvegicus) with allometrically scaled dose of Ketamine, Xylazine, Acepromazine and Atropine - preliminary report. Arq Cienc Vet Zool UNIPAR 6: 195-195.

Pitsouni E, Alexiou V, SARidakis V, Peppas G AND FALAGAS ME. 2009. Dos the use of probiotics/synbiotics prevent postoperative infections in patients undergoing abdominal surgery A meta-analysis of randomized controlled trials. Eur J Clin Pharmacol 65: 561-570.
Rodrigues MAM, De CAMARgo JLV, CoElHo KIR, Montenegro MRG, ANGEline AYO AND BURInI RC. 1985. Morphometric study of the small intestinal in young, adult, and old rats submitted to protein deficiency and rehabilitation. Gut 26: 816-821.

SChOFFEN JPF, SoARES A, DE Freitas P, ButTow NC AND NATALI MRM. 2005. Effects of a hypoproteic diet on myosin- $\mathrm{V}$ immunostained myenteric neurons and the proximal colon wall of aging rats. Auton Neurosci 122: 77-83.

TORREJAIS MM, NATALI MRM, CONEGERO CI AND MIRANDA NETO MH. 1995. Effects of proteic malnutrition after breast-feeding on the morphology if the intestinal wall and myenteric neurons of the ileum of rats. Rev Unimar 17: 315-327.

Villena J, Racedo S, Agüero G and Alvarez S. 2006. Yoghurt accelerates the recovery of defence mechanisms against Streptococcus pneumonia in protein-malnourished mice. Brit J Nutr 95: 591-602.

VITERI FE AND SCHNEIDER MD. 1974. Gastrointestinal alterations in protein-calorie malnutrition. Sym Gastr Phys 58: $1487-1505$.

WATERLOW CJ. 1996. Malnutrition proteico-energetica. Washington: Organización Panamericana de la Salud, 489 p. 